\title{
Review Article \\ Euonymus alatus: A Review on Its Phytochemistry and Antidiabetic Activity
}

\author{
Xifeng Zhai, ${ }^{1,2}$ George Binh Lenon, ${ }^{1}$ Charlie C. L. Xue,, and Chun-Guang Li ${ }^{1,3}$ \\ ${ }^{1}$ Traditional \& Complementary Medicine Program, School of Health Sciences, RMIT University, Bundoora, VIC 3083, Australia \\ ${ }^{2}$ School of Pharmaceutical Sciences, Xi'an Medical University, Xi'an 710021, China \\ ${ }^{3}$ National Institute of Complementary Medicine, Western Sydney University, Penrith, NSW 2751, Australia
}

Correspondence should be addressed to Chun-Guang Li; c.li@westernsydney.edu.au

Received 19 May 2016; Accepted 10 July 2016

Academic Editor: Bashar Saad

Copyright (C) 2016 Xifeng Zhai et al. This is an open access article distributed under the Creative Commons Attribution License, which permits unrestricted use, distribution, and reproduction in any medium, provided the original work is properly cited.

\begin{abstract}
Euonymus alatus (E. alatus) is a medicinal plant used in some Asian countries for treating various conditions including cancer, hyperglycemia, and diabetic complications. This review outlines the phytochemistry and bioactivities of $E$. alatus related to antidiabetic actions. More than 100 chemical constituents have been isolated and identified from E. alatus, including flavonoids, terpenoids, steroids, lignans, cardenolides, phenolic acids, and alkaloids. Studies in vitro and in vivo have demonstrated the hypoglycemic activity of $E$. alatus extracts and its certain constituents. The hypoglycemic activity of $E$. alatus may be related to regulation of insulin signaling and insulin sensitivity, involving PPAR $\gamma$ and aldose reductase pathways. Further studies on E. alatus and its bioactive compounds may help to develop new agents for treating diabetes and diabetic complications.
\end{abstract}

\section{Introduction}

Euonymus alatus (E. alatus) is a medicinal plant used traditionally in many Asian countries, including China and Korea, for treating various conditions. It has long been used in China as a Chinese Materia Medica for pain and menstrual disorders. The first record of its clinical use in China was documented in Shen Nong Ben Cao Jing (The Classic of Herbal Medicine) written between $300 \mathrm{BC}$ and $200 \mathrm{AD}$. Ben Cao Gang $M u$ (Compendium of Materia Medica, AD1578, written by Li Shizhen) later recorded its applications for vaginal bleeding, abdominal distention, and detoxification, and Ben Cao Jing Ji Zhu (Collective Notes to Canon of Materia Medica) recorded its use for abdominal pain, killing worms, and eliminating skin swelling caused by various reasons [1]. The interest in $E$. alatus has been increased recently largely due to the research on its bioactivities against cancer and diabetes. Recent studies have demonstrated a wide range of bioactivities of $E$. alatus, including hypoglycemic, antihypertensive [2], antitumor [3, 4], sedative [2], and regulation of blood lipid $[5,6]$ and immune functions [7]. There is also clinical evidence for its efficacy against hyperglycemia [8], chronic nephropathy [9], rheumatoid arthritis [10], cor pulmonale [11], bronchial asthma [12], anaphylactic disease [13, 14], urinary tract infection, and prostate diseases [15]. This short review outlines the phytochemistry of E. alatus and its pharmacology related to antidiabetic actions.

\section{Phytochemistry}

More than 128 chemical constituents have been isolated and identified from E. alatus. The main chemical classes include flavonoids, terpenoids, steroids, lignans, cardenolides, phenolic acids, and alkaloids.

2.1. Flavonoids. A total of 26 flavonoids have been isolated and identified from E. alatus. The main structure types include flavonoid, flavanone, and flavonol. The aglycones of flavonoid glycosides isolated from $E$. alatus include quercetin, kaempferol, naringenin, aromadendrene, and dihydroquercetin. The flavonoids are mainly distributed in the leaves and wings of $E$. alatus [16]. The structures of main flavonoids identified in E. alatus are listed in Tables 1-4. 
TABLE 1: Quercetin and glycosides in E. alatus.

\begin{tabular}{|c|c|c|c|c|c|}
\hline Skeleton & Number & Name & $\mathrm{R}_{1}$ & $\mathrm{R}_{2}$ & Reference \\
\hline \multirow{6}{*}{$\mathrm{R}_{2} \mathrm{O}$} & 1 & Quercetin & $\mathrm{H}$ & $\mathrm{H}$ & $\begin{array}{l}{[24,39} \\
48-50]\end{array}$ \\
\hline & 2 & Quercitrin & $\alpha$-L-Rhamnose & $\mathrm{H}$ & {$[17,49]$} \\
\hline & 3 & $\begin{array}{l}\text { Quercetin-7-O- } \alpha \text {-L- } \\
\text { rhamnoside }\end{array}$ & $\mathrm{H}$ & $\alpha$-L-Rhamnose & [50] \\
\hline & 4 & $\begin{array}{l}\text { Quercetin-3,7-O- } \alpha-\mathrm{L}- \\
\text { dirhamnoside }\end{array}$ & $\alpha$-L-Rhamnose & $\alpha$-L-Rhamnose & {$[17,50]$} \\
\hline & 5 & $\begin{array}{l}\text { Quercetin 3-D-galactoside } \\
\text { (hyperin) }\end{array}$ & 3-D-Galactose & $\mathrm{H}$ & {$[17,20]$} \\
\hline & 6 & Rutin & $\begin{array}{c}\alpha \text {-L-Rhamnopyranosyl- } \\
(1 \rightarrow 6)-\beta \text {-D-glucopyranose }\end{array}$ & $\mathrm{H}$ & [39] \\
\hline
\end{tabular}

TABLE 2: Kaempferol and the glycosides in E. alatus.

\begin{tabular}{|c|c|c|c|c|c|}
\hline Skeleton & Number & Name & $\mathrm{R}_{1}$ & $\mathrm{R}_{2}$ & Reference \\
\hline \multirow{5}{*}{$\mathrm{R}_{2} \mathrm{O}$} & 7 & Kaempferol & $\mathrm{H}$ & $\mathrm{H}$ & $\begin{array}{c}{[18,21,48,} \\
49]\end{array}$ \\
\hline & 8 & $\begin{array}{l}\text { Kaempferol-7-O- } \alpha \text {-L- } \\
\text { rhamnoside }\end{array}$ & $\mathrm{H}$ & $\alpha$-L-Rhamnose & {$[50]$} \\
\hline & 9 & $\begin{array}{c}\text { Kaempferol-3,7-O- } \alpha \text {-L- } \\
\text { rhamnoside } \\
\text { (kaempferitrin) }\end{array}$ & $\alpha$-L-Rhamnose & $\alpha$-L-Rhamnose & {$[17,50]$} \\
\hline & 10 & $\begin{array}{c}\text { Kaempferol-7-O- } \beta \text {-D- } \\
\text { glucoside }\end{array}$ & $\mathrm{H}$ & $\alpha$-L-Glucose & {$[50]$} \\
\hline & 11 & $\begin{array}{l}\text { Apigenin-3-O-L- } \\
\text { rhamnopyranoside }\end{array}$ & $\alpha$-L-Rhamnose & $\mathrm{H}$ & [49] \\
\hline
\end{tabular}

Other flavonoids include catechin (19) [17-21], symplocoside (20) [17], quercetin-3-galactosyl-xyloside (21) [20], catechin lactone A (22) [17], dehydrodicatechin A (23) [17-21], 3-hydroxycoumarinflavanol (24), 7,4' dihydroxy-8-C-glucoxylisoflavone (25) [22], and 5-hydroxy6,7-dimethoxyflavone (26) [23].

2.2. Steroids. Eight steroids including sterols and sterones have been isolated and identified from E. alatus. The main structures of the steroids are shown in Table 5. Other steroids include 24R-methyllophenol (34) and $\alpha$-spinasterol (35) [22].

2.3. Terpenoids. The main terpenoids isolated from E. alatus include triterpenes and sesquiterpenes.

2.3.1. Triterpenes. Multiple types of triterpenes were found in E. alatus. Most of the triterpenes in E. alatus belong to lupane type and oleanane type. Other types include hopane, ursane, and friedelane. Table 6 shows the lupane type and friedelane type triterpenes isolated from E. alatus.

Other triterpenes include oleanic acid (45), wilforlide A (46) [24], hop-(22)-29-en-3 $\beta$-ol (47) [25], 3 $\beta$-hydroxy$21 \alpha$ H-hop-22(29)-en-30-ol (48), $2 \alpha, 3 \beta$-dihydroxyurs-12,19dien-23,28-oic acid (49) [21], arborinone (50), taraxerol (51) and germanicol (52) [22], 11-keto- $\beta$-boswellic acid (53), acetyl 11-keto- $\beta$-boswellic acid (54), camaldulenic acid (55) [23], 3 $\beta, 28,30$-lup-20(29)-ene triol (56), 28,30-dihydroxy-3oxolup-20(29)-ene (57), glut-5-en-3 $\beta$-ol (58), maslinic acid (59), hederagenin (60), 3-oxo-11alpha-methoxyolean-12-ene (61), 3 $\beta$-hydroxy-1-oxo-olean-12-en-28-oic acid (62), ursolic acid (63), and $2 \alpha$-hydroxy-ursolic acid (64) [26]. The structures of compounds 45-64 are shown in Figure 1.

2.3.2. Sesquiterpenes. Two new sesquiterpenes $(65,66)$ and two known ones were isolated from $95 \%$ ethanol extract of the stems of E. alatus. The known ones were identified as $6 \alpha, 12$-diacetoxy-2b,9 $\alpha$-di(b-furancarbonyloxy)- $4 \alpha$-hydroxyl-1 $\beta$-(2-methylbutanoyloxy)- $\beta$-dihydroagarofuran (67), $1 \alpha, 2 \alpha, 6 \beta$-triacetoxy- $4 \beta$-hydroxy- $9 \beta$ - $(\beta-)$ furancarboxy-15[(amethyl) butyroyloxy]- $\beta$-dihydroagarofuran (68) [27]. The structures of sesquiterpenes isolated from E. alatus are shown in Figure 2.

2.4. Alkaloids. Five alkaloids have been isolated from $E$. alatus and identified as alatamine (69), alatusamine (70) and alatusinine (71) [28], 1 $\beta, 2 \beta, 5 \alpha, 8 \beta, 11$-pentaacetoxy$4 \alpha$-hydroxy-3 $\alpha$-(2-methylbutanoyl)-15-nicotinoyl-7-oxo-

dihydroagarofuran (72), evonine (73), and neoevonine (74) [27]. The structures of alkaloids isolated from E. alatus are shown in Figure 3. 
TABLE 3: Apigenin and glycoside in E. alatus.

\begin{tabular}{|c|c|c|c|c|c|}
\hline Skeleton & Number & Name & $\mathrm{R}_{1}$ & $\mathrm{R}_{2}$ & Reference \\
\hline & 12 & Apigenin & $\mathrm{H}$ & $\mathrm{H}$ & {$[48]$} \\
\hline $\mathrm{R}$ & 13 & Acacetin-7-O-rutinoside (Linarin) & Rutinose & $\mathrm{H}$ & [18] \\
\hline
\end{tabular}

TABLE 4: Flavanone and the glycoside in E. alatus.

\begin{tabular}{|c|c|c|c|c|c|c|c|}
\hline Skeleton & Number & Name & $\mathrm{R}_{1}$ & $\mathrm{R}_{2}$ & $\mathrm{R}_{3}$ & $\mathrm{R}_{4}$ & Reference \\
\hline \multirow{5}{*}{$\mathrm{R}_{2} \mathrm{O}$} & 14 & Dihydroquercetin & $\mathrm{OH}$ & $\mathrm{H}$ & $\mathrm{OH}$ & $\mathrm{H}$ & {$[49,50]$} \\
\hline & 15 & Aromadendrene & $\mathrm{OH}$ & $\mathrm{H}$ & $\mathrm{H}$ & $\mathrm{H}$ & $\begin{array}{l}{[19,39} \\
49,50]\end{array}$ \\
\hline & 16 & Naringenin & $\mathrm{H}$ & $\mathrm{H}$ & $\mathrm{H}$ & $\mathrm{H}$ & {$[48-50]$} \\
\hline & 17 & Naringin & $\mathrm{H}$ & Neohesperidose & $\mathrm{H}$ & $\mathrm{H}$ & {$[18]$} \\
\hline & 18 & Hesperidin & $\mathrm{H}$ & Rutinose & $\mathrm{OH}$ & $\mathrm{CH}_{3}$ & {$[50]$} \\
\hline
\end{tabular}

TABLE 5: Steroids in E. alatus.

\begin{tabular}{|c|c|c|c|c|}
\hline \multirow[t]{7}{*}{ Skeleton } & Number & Name & $\mathrm{R}$ & References \\
\hline & 28 & $\beta$-Sitosterol & $\mathrm{OH}$ & $\begin{array}{c}{[18,20,24,39} \\
51,52]\end{array}$ \\
\hline & 29 & $\beta$-Sitosterone & $=\mathrm{O}$ & {$[51]$} \\
\hline & 30 & Daucosterol & Glucose & {$[21,48]$} \\
\hline & 31 & Stigmast-4-en-3-one (sitostenone) & $\mathrm{H}$ & {$[51,52]$} \\
\hline & 32 & $6 \beta$-Hydroxy-stigmast-4-en-3-one & $\mathrm{OH}$ & {$[51,52]$} \\
\hline & 33 & Stigmast-4-en-3,6-dione & $=\mathrm{O}$ & {$[51]$} \\
\hline & & & & \\
\hline
\end{tabular}

TABLE 6: Lupane type and friedelane type triterpenes in E. alatus.

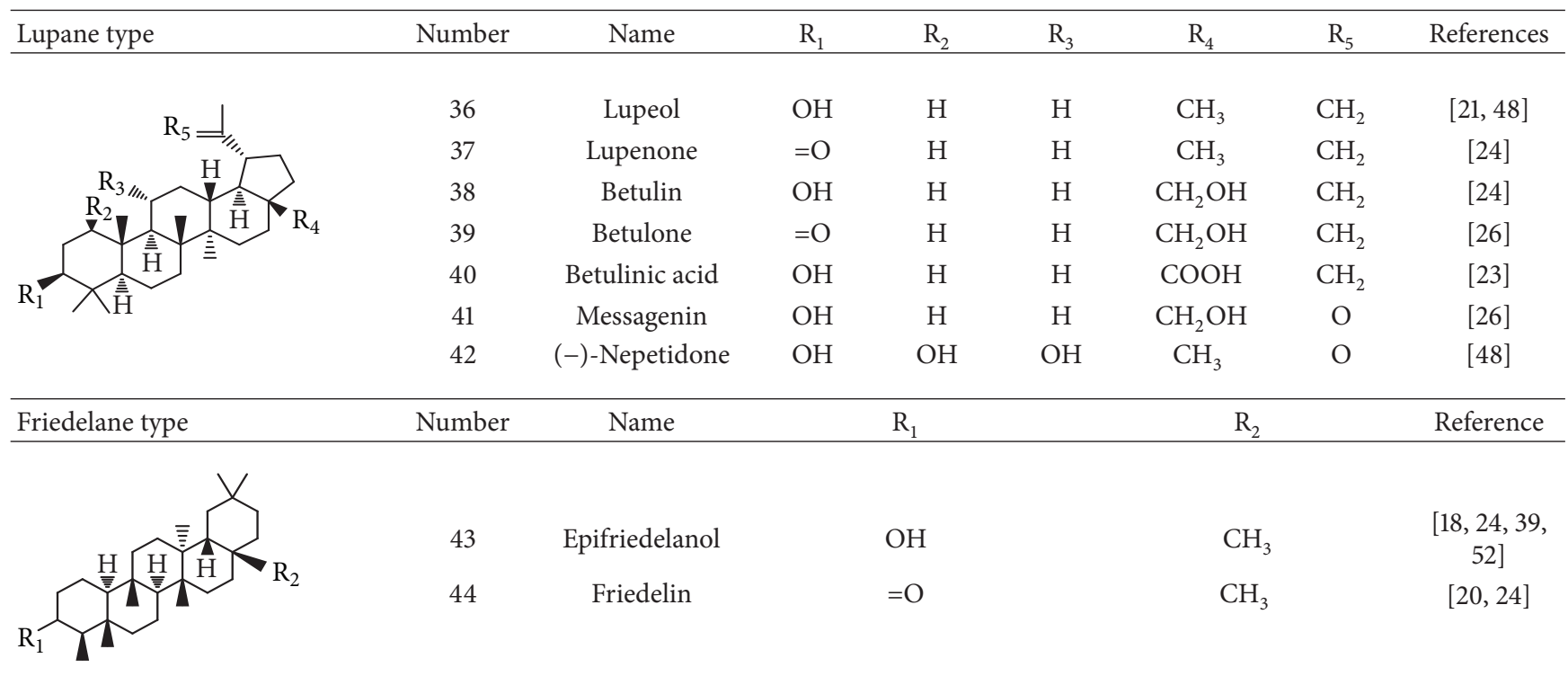




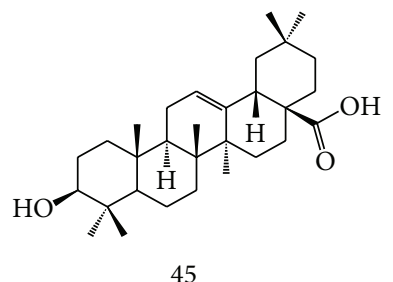

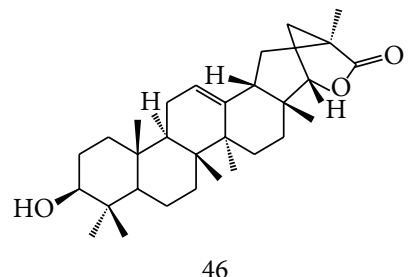<smiles>C=C(C)C1CCC2CCC3C(CCC21)CCC1C3(C)CCC2C(C)(C)C(O)CCC21C</smiles>

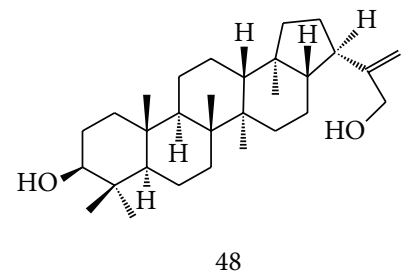

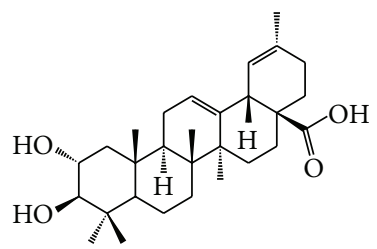

49<smiles>CC(C)C1CCC2C1(C)CCC1C3(C)CCC4C(C)(C)C(=O)CCC4(C)C3=CC[C@@]12C</smiles>

50

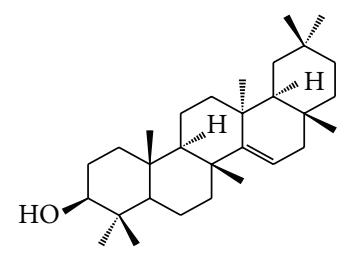

51<smiles>CC1(C)C=C2C3CCC4(C)CCC(O)C(C)(C)C4CCC(C)(C)C3(C)CC[C@@H]2C2(C)CCC1C2</smiles>

52<smiles>CC1CCC2(C)CCC3(C)C(=CC(=O)[C@H]4C3CCC3[C@H](C(O)O)C(O)CC[C@@]34C)[C@H]2C1C</smiles>

53<smiles>C=C(CO)C1CCC2(CO)CCC3(C)C(CCC4C3CCC3C(C)(C)C(=O)CC[C@]43C)C12</smiles>

57

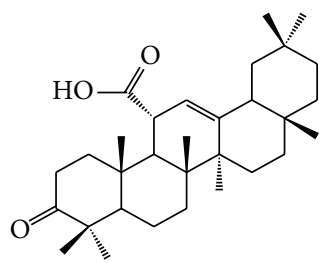

61

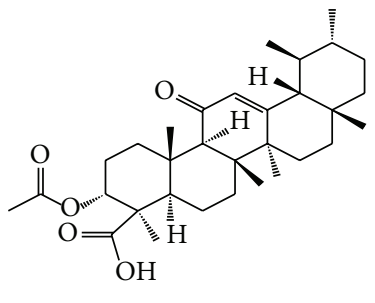

54<smiles>CC1(C)CCC2C3CCC4C5CCC(O)C(C)(C)C5=CC[C@@]4(C)[C@]3(C)CCC2(C)CC1</smiles>

58<smiles>CC1(C)CCC2(C(=O)O)CC[C@]3(C)C(=CCC4C3(C)CCC3C(C)(C)[C@@H](O)CC(=O)[C@@]34C)C2C1</smiles>

62

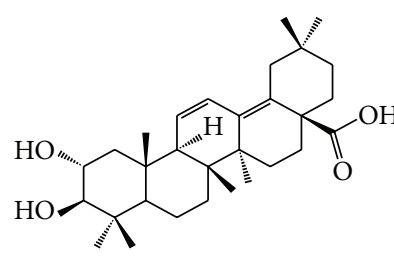

55

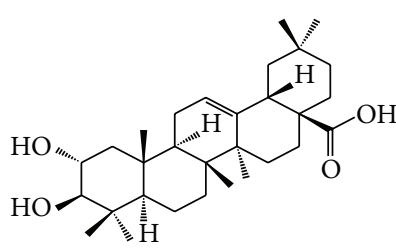

59

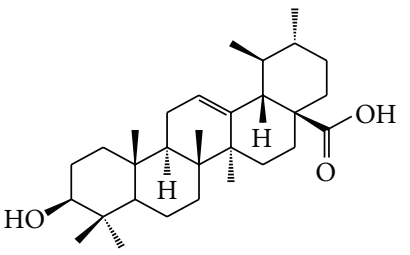

63<smiles>C=C(CO)[C@H]1CCC2(CO)CC[C@]3(C)C(CCC4C5(C)CC[C@@H](O)C(C)(C)C5CCC43C)C12</smiles>

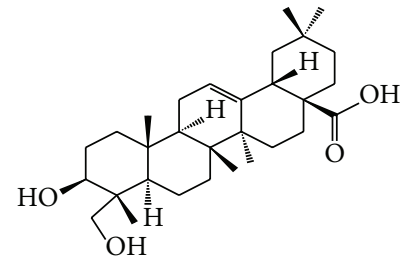

60<smiles>CC1CCC2(C(=O)O)CCC3(C)C4CCC5C(CC(O)C(O)C5(C)C)[C@@]4(C)C[C@H]3CC=C2[C@H]1C</smiles>

64

FIGURE 1: The structures of compounds 45-64 isolated from E. alatus.

2.5. Cardenolides. Kitanaka et al. [3] isolated three cytotoxic cardenolides from the woods of $E$. alatus and identified them as acovenosigenin A 3-O- $\alpha$-L-rhamnopyranoside (75), euonymoside A (76), and euonymusoside A (77).

2.6. Lignans. Jeong et al. [29] identified three new lignans from $80 \%$ methanolic extract of $E$. alatus leaves and twigs, including (-)-threo- $4,9,4^{\prime}, 9^{\prime}$-tetrahydroxy$3,7,3^{\prime}, 5^{\prime}$-tetramethoxy-8-O- $8^{\prime}$-neolignan (78), (-)-threo$4,9,4^{\prime}, 9^{\prime}$-tetrahydroxy-3,5,7,3' -tetramethoxy-8-O- $8^{\prime}$-neolignan (79), and $\left(7 \mathrm{R}, 8 \mathrm{R}, 7^{\prime} \mathrm{R}\right)-(+)$-lyoniresinol (80). The other known compounds identified include (+)simulanol (81), (+)-dehydrodiconiferyl alcohol (82), (-)-simulanol (83), (-)-dehydrodiconiferyl alcohol (84), (+)dihydrodehyrodiconiferyl alcohol (85), 7R,8S-guaiacylglycerol-8-O-4 ${ }^{\prime}$-(coniferyl alcohol) ether (86), 7S,8R-guaiacylglycerol-8-O-4'-(coniferyl alcohol) ether (87), 7S,8Rsyringylglycerol-8-O-4' -( sinapyl alcohol) ether (88), 7S,8Sguaiacylglycerol-8-O- $4^{\prime}$-( sinapyl alcohol) ether (89),7S,8S$4,9,9^{\prime}$-trihydroxy-3, $3^{\prime}$-dimethoxy-8-O- $4^{\prime}$-neolignan (90), 7R,8R-4,9, $9^{\prime}$-trihydroxy-3, $3^{\prime}$-dimethoxy-8-O-4 -neolignan (91), (+)-syringaresinol (92), de- $4^{\prime}$-methylyangabin (93), hedyotol C (94), threo-buddlenol B (95), hedyotisol C (96), 


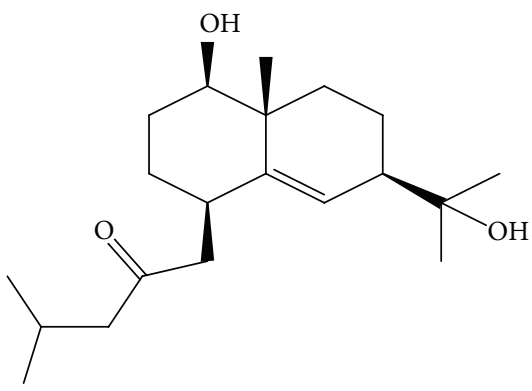

65

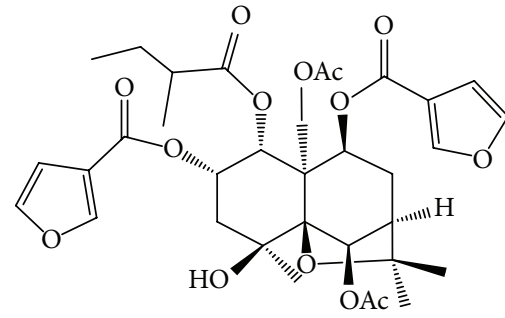

67

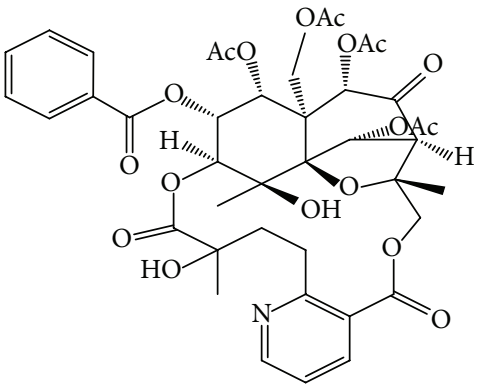

69 alatamine

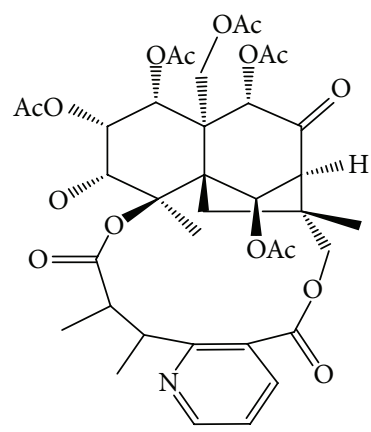

73

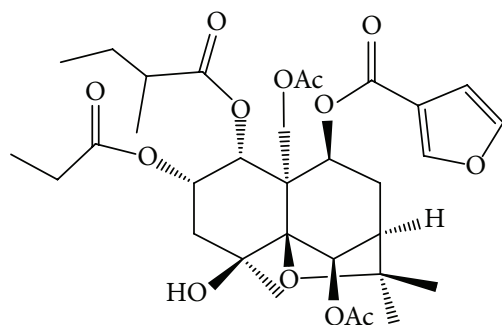

66

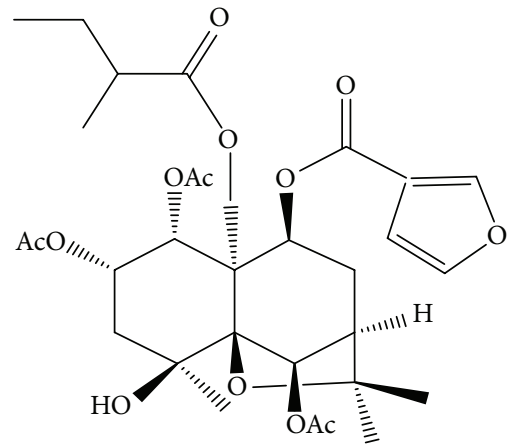

68

FIGURE 2: Structures of sesquiterpenes (compounds 65-68) isolated from E. alatus.

FIGURE 3: Structures of alkaloids (compounds 69 and 71-74) isolated from E. alatus. 
and hedyotisol B (97). The structures of compounds 78-97 are shown in Figure 4.

2.7. Other Constituents. E. alatus also contains organic acids, esters, and aldehydes, as illustrated examples in Table 7.

In addition, 3,4-dihydroxybenzoic acid (114), p-propoxybenzoic acid (115), p-coumaric acid (116), ferulic acid (117), 1-feruloyl- $\beta$-D-glucoside (118), tetradecyl (E)-ferulate (119) [22], ethyl 2,4-dihydroxy-6-methylbenzoate (120), 4,4' dimethoxy-1,1' -biphenyl (121) [23], squalene (122) [25], 1octacosanol (123) [24], n-hexacosanoic acid (124) [18, 24], 1,30-triacontanediol (125), tetracosanoic acid (126), n-octane (127), and n-nonane (128) [21] were also isolated from $E$. alatus. In a study of essential oil from $E$. alatus by using GCMS, 56 volatile components were identified. The main volatile components include carboxylic acid, aldehyde, ketone, terpenoid, and derivatives of oxygenated terpenoid. Among these the highest content is hexadecanoic acid (39.69\%), followed by wintergreen (5.02\%) [30].

\section{Antidiabetic Activity}

The effects of E. alatus extracts have been tested in vivo. In streptozotocin (STZ) treated diabetic rats, an aqueous extract of E. alatus reduced the body weight, the fasting plasma glucose level, and glucose tolerance. The serum levels of insulin, glucagon, cholesterol, and triglyceride were also reduced [31]. Similar results were obtained in high-fat plus low dose STZ diabetic rats, showing that E. alatus treated rats had lower levels of fasting blood glucose and insulin and decreased levels of blood lipids and inflammatory mediators (TNF- $\alpha$, C-reactive protein), indicating that $E$. alatus can improve the glucose-lipid metabolism and insulin resistance in diabetic conditions [32]. Park et al. also demonstrated that an ethanol extract of E. alatus reduced the body weight, increased insulin sensitivity, and corrected the associated hyperinsulinemia and hyperlipidemia in high-fat diet-induced hyperglycemic and hyperlipidemic ICR mice [33].

The antihyperglycemic effect of E. alatus may involve a protection of functional islet $\beta$ cells since $E$. alatus treated animals were shown with more positive staining of islet $\beta$ cells than those in diabetic controls [34]. Other studies in ICR mice indicate that E. alatus may affect glucose and lipid homeostasis via a regulation of hepatic lipogenesis related genes (SREBPla, FAS, and GAPT) and PPAR $\gamma$ gene expressions in periepididymal fat. The plausible mechanism of hypoglycemic and hypolipidemic actions of E. alatus extract is illustrated in Figure 5 [33].

In addition, a study showed that E. alatus protected rats from experimental diabetic nephropathy induced by uninephrectomy plus STZ treatment, with 12-week administration of E. alatus extract and irbesartan (positive control) decreased HbAlc and pathological changes (extracellular matrix expansion and glomerulosclerosis) in kidney and improved blood lipids profile and kidney function; the effect was associated with a downregulation of transform growth factor $\beta_{1}$ expression [35]. In addition, E. alatus was shown to inhibit polyol pathway, which is known to be associated with chronic diabetic complications such as neuropathy, nephropathy, and retinopathy [36].

Fang et al. studied the antidiabetic effects of different fractions of $E$. alatus extracts (including petroleum ether, diethyl ether, ethyl acetate, n-butanol, and water fraction) in alloxan-induced diabetic mice and high-fat diet diabetic mice and found that ethyl acetate fraction significantly reduced plasma glucose and glucose tolerance in both normal and diabetic mice [37] and also reduced total cholesterol and triglyceride contents and increased SOD activity in diabetic mice [37]. Further analysis revealed that the main components in the ethyl acetate fraction were flavonoids and phenolic acids, including quercetin and kaempferol, which were known for their antioxidant activities [37]. In another study, different extract fractions of E. alatus, including aqueous, diethyl ether, and ethyl acetate fractions, were tested in alloxan induced diabetic mice at a dose of $10 \mathrm{~g} / \mathrm{kg}$ and it was found that the aqueous extract was the most active in decreasing blood glucose and lipid levels and improved glucose tolerance [6]. Thus, E. alatus may contain multiple active antidiabetic constituents. Similarly, a study on the hypoglycemic fractions of six fractions of E. alatus extracts (including petroleum ether, ethyl acetate, n-butanol, water, residue, and rectified polysaccharide) in diabetic rats found that the fractions of petroleum ether, water, and ethyl acetate had significant antidiabetic effects. Fractions of n-butanol and rectified polysaccharide reduced blood creatinine, and other fractions reduced urea level. The residue fraction decreased the low-density lipoprotein (LDL) and cholesterol contents. The body weight was increased by the treatment with all fractions except rectified polysaccharide. These results indicate that different active compounds in these fractions may be responsible for the observed effects of E. alatus, including antidiabetic, antihyperlipidemic, kidney function improvement, blood viscosity decrease, and body weight affecting [38], and the active antidiabetic compounds are likely to be from the petroleum ether, water, and ethyl acetate fractions. In another study, an ethyl acetate extract of E. alatus was shown with hypoglycemic effect, and four compounds were isolated from this fraction and identified as p-hydroxybenzoic acid (EA-1), protocatechuic acid (EA-2), 4-hydroxy-3-methoxybenzoic acid (EA-3), and 3, 5-dimethoxy-4-hydroxybenzoic acid (EA-4) [8]. Others reported identification of six compounds with hyperglycemic activity from the $90 \%$ ethanol extracts of E. alatus, including aromadendrin, epifriedelanol, protocatechuic acid, $\beta$ sitosterol, quercetin, and rutin [39]. The active components in protecting experimental diabetic nephropathy as mentioned above have also been suggested to be concentrated in ethyl acetate and $n$-butanol fractions $[36,40]$, though the nature of these compounds is still not identified.

Jeong et al. (2015) studied the inhibitory effects of 23 compounds isolated from $E$. alatus on protein tyrosine phosphatases $1 \mathrm{~B}$ (PTP1B) and $\alpha$-glucosidase activities and found that lupenone, lupeol, taraxerol, p-propoxybenzoic acid, 1-feruloyl- $\beta$-D-glucoside, and 3-hydroxycoumarinflavanol exhibited inhibitory activity against PTP1B with $\mathrm{IC}_{50}$ values ranging from 5.6 to $18.4 \mu \mathrm{M}$. 24R-methyllophenol, arborinone, and $p$-propoxybenzoic acid were shown with a similar 
<smiles>[Y9]c1cc(C(OC)C(CO)OC(CO)Cc2cc(Br)c(O)c(OC)c2)cc(OC)c1O</smiles>

$78 \mathrm{R}_{1}=\mathrm{OCH}_{3}, \mathrm{R}_{2}=\mathrm{H}$

$79 \mathrm{R}_{1}=\mathrm{H}, \mathrm{R}_{2}=\mathrm{OCH}_{3}$

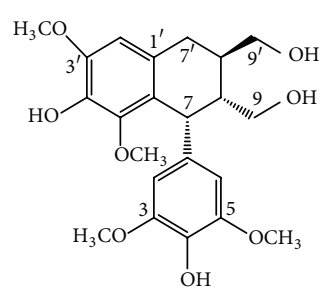

80<smiles>[2H]c1cc([C@H]2Oc3c(OC)cc(/C=C/CO)cc3[C@@H]2CO)cc(OC)c1O</smiles>

$81 \mathrm{R}=\mathrm{OCH}_{3}$ $82 \mathrm{R}=\mathrm{H}$

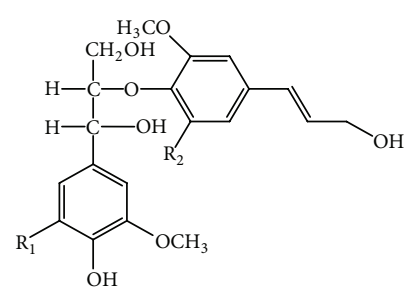

$86 \mathrm{R}_{1}=\mathrm{H}, \mathrm{R}_{2}=\mathrm{H}$, erythro-7R, $8 \mathrm{~S}$

$87 \mathrm{R}_{1}=\mathrm{H}, \mathrm{R}_{2}=\mathrm{H}$, erythro-7S, $8 \mathrm{R}$

$88 \mathrm{R}_{1}=\mathrm{OCH}_{3}, \mathrm{R}_{2}=\mathrm{OCH}_{3}$, erythro-7S, $8 \mathrm{R}$<smiles>[2H]c1cc([C@H]2Oc3c(OC)cc(/C=C/CO)cc3[C@@H]2CO)cc(OC)c1O</smiles>

$83 \mathrm{R}=\mathrm{OCH}_{3}$ $84 \mathrm{R}=\mathrm{H}$

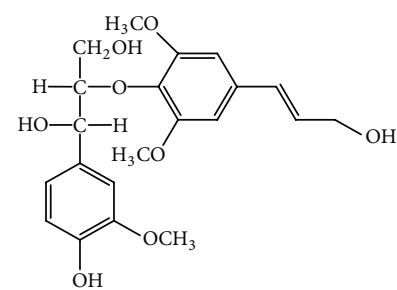

89 threo-7S, 8 S

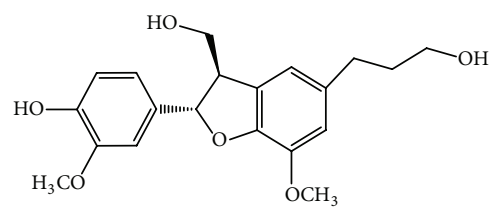

85

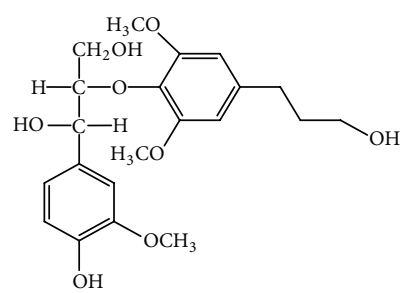

90 threo-7S, $8 \mathrm{~S}$

91 threo-7R, 8R<smiles></smiles>
$92 \mathrm{R}=\mathrm{H}$
$93 \mathrm{R}=\mathrm{OCH}_{3}$<smiles>COc1cc(C(O)C(CO)Oc2c(OC)cc(C3OCC4C(c5ccc(O)c(OC)c5)OCC34)cc2OC)ccc1O</smiles>

94

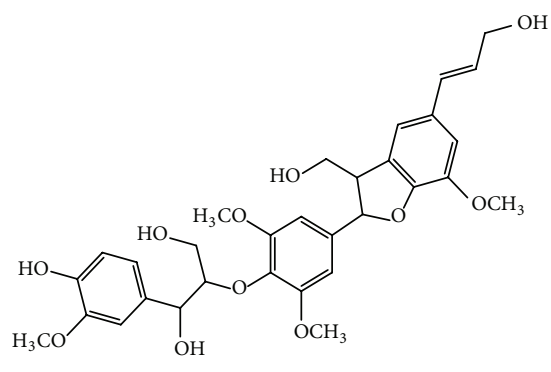

95

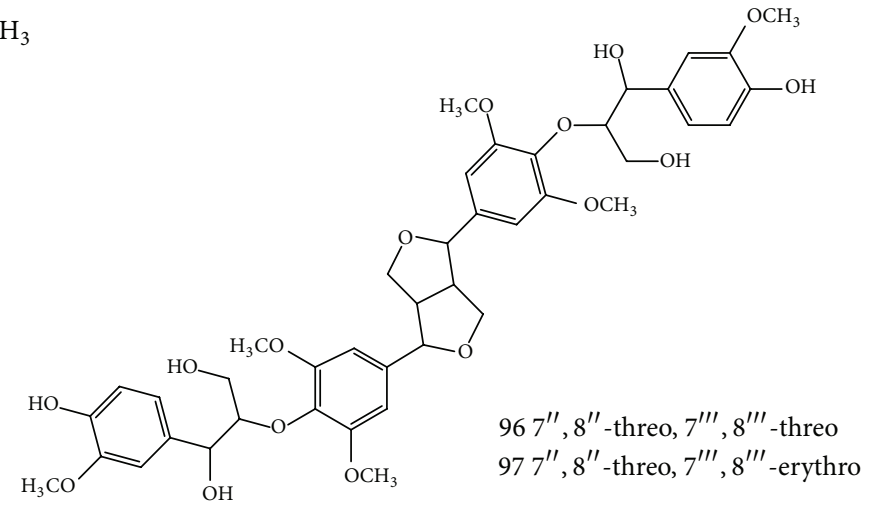

FIgURE 4: Structures of compounds 78-97 isolated from leaves and twigs of E. alatus, modified from [29]. 
TABLE 7: Illustrated examples of other constituents in E. alatus.

\begin{tabular}{|c|c|c|c|}
\hline Number & Name & Chemical structure & Reference \\
\hline 98 & Usnic acid & & {$[24,48]$} \\
\hline 99 & Protocatechuic acid & & {$[18,39]$} \\
\hline 100 & $\begin{array}{l}\text { 2-Hydroxy-4-methoxy-3,6- } \\
\text { dimethylbenzoic acid }\end{array}$ & & {$[48]$} \\
\hline 101 & Benzoic acid & & {$[24,48]$} \\
\hline 102 & $\begin{array}{l}\text { Methyl 2,4-dihydroxy-6-methyl } \\
\text { benzoate }\end{array}$ & & {$[52]$} \\
\hline 103 & $\begin{array}{l}\text { 2,4-Dihydroxy-3,6- } \\
\text { dimethylbenzoate }\end{array}$ & & {$[21,52]$} \\
\hline 104 & 7-Methoxy-4-methyl phthalide & & {$[52]$} \\
\hline 105 & Caffeine & & {$[25]$} \\
\hline 106 & Caffeic acid & & {$[49,53]$} \\
\hline 107 & Chlorogenic acid & & {$[54]$} \\
\hline 108 & Vanillin & & {$[52]$} \\
\hline 109 & 5-Hydroxymethyl furfural & $\mathrm{H}$ & {$[25]$} \\
\hline 110 & Dulcitol & & {$[20]$} \\
\hline 111 & Grasshopper ketone & & [49] \\
\hline
\end{tabular}


TABLE 7: Continued.

\begin{tabular}{lclll}
\hline Number & Name & Suberone \\
112 & Syringin & Reference
\end{tabular}

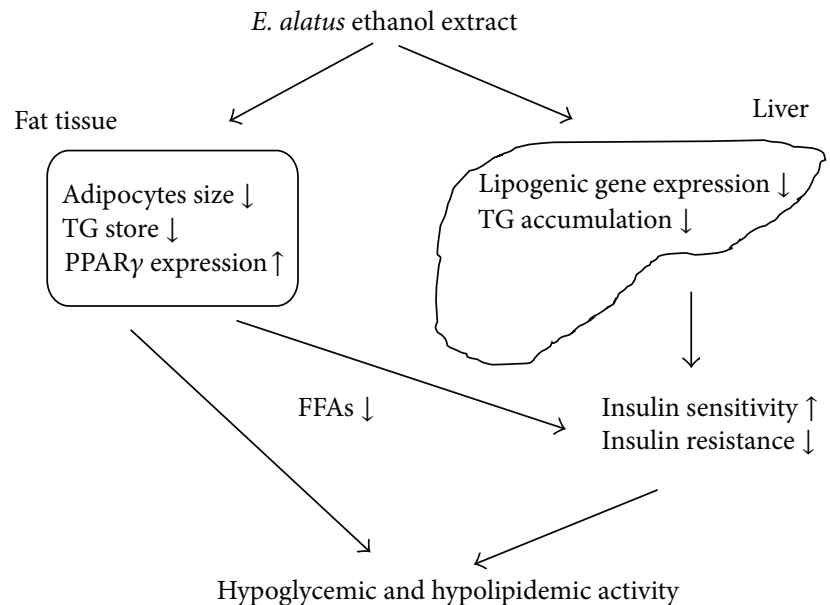

Figure 5: Possible mechanism of hypoglycemic and hypolipidemic actions of E. alatus ethanol extract, modified from [33].

activity with $\mathrm{IC}_{50}$ values of $15.1,23.6$, and $14.8 \mu \mathrm{M}$, respectively. On the other hand, $p$-propoxybenzoic acid, tetradecyl (E)-ferulate, and 3-hydroxycoumarinflavanol exhibited inhibition on $\alpha$-glucosidase with $\mathrm{IC}_{50}$ values of $10.5,9.5$, and 9.1 $\mu \mathrm{M}$, respectively [22].

Studies on kaempferol and quercetin, the active constituents of E. alatus, demonstrated that these compounds improved insulin-stimulated glucose uptake in mature 3T3L1 adipocytes [41]. kaempferol and quercetin were shown to act as weak partial agonists in the PPAR $\gamma$ reporter gene assay, without inducing differentiation of 3T3-L1 preadipocytes as traditional PPAR $\gamma$ agonists. When kaempferol and quercetin were added together with the PPAR $\gamma$ agonist rosiglitazone, the 3T3-L1 differentiation was inhibited in a dose-dependent manner. Competitive ligand-binding assay confirmed that kaempferol and quercetin competed with rosiglitazone at the same binding pocket site as PPAR $\gamma$. These compounds were also shown with significant inhibitory effects on NO production in response to lipopolysaccharide treatment in macrophage cells in which the PPAR $\gamma$ was overexpressed. These findings suggest that kaempferol and quercetin may act on multiple targets to ameliorate hyperglycemia [41].

Ivorra et al. studied the effects of daucosterol $(\beta$-sitosterol 3 - $\beta$-glucoside) and its aglycone $(\beta$-sitosterol) on plasma insulin and glucose levels in normo- and hyperglycemic rats and found that oral administration of daucosterol or $\beta$-sitosterol increased the fasting plasma insulin levels. In addition, both compounds improved the oral glucose tolerance and increased glucose-induced insulin secretion [42]. In addition, rutin, one of the constituents of $E$. alatus, has been shown to decrease the plasma levels of glucose and lipids and increase the expression of PPAR $\gamma$ mRNA and protein in skeletal muscles of $\mathrm{db} / \mathrm{db}$ mice [43]. Rutin was also demonstrated with an AR inhibition activity $\left(\mathrm{IC}_{50}\right.$ $3.01 \mu \mathrm{M})$ [44]. Quercitrin, a flavonoid glycoside in E. alatus, was demonstrated as a noncompetitive AR inhibitor. It blocked polyol accumulation in intact rat lenses incubated in medium containing high concentration of sugars [45]. Other compounds, such as linarin (acacetin-7-O- $\beta$-D-rutinoside), have also been demonstrated with inhibitory activity against $\alpha$-glucosidase [46].

3.1. Clinical Evidence. There have been limited clinical studies, mostly case reports, on the antidiabetic actions of $E$. alatus containing formulae (Table 8). In addition, a controlled trial, involving two groups of patients (40 patients in each group) with impaired glucose tolerance, showed that the group treated with diet and exercise intervention plus $E$. alatus formula for 1 month had significantly reduced blood glucose levels, compared to that in the diet and exercise control group. The effective rate was $80 \%$ in the E. alatus treatment group, compared to that of $55 \%$ in the control group [47]. It should be pointed out in most of these studies that $E$. alatus was not used lone, but in combination with other herbs; thus it is not clear if the observed effects are due to E. alatus or through interactions with other herbs. Thus, there may be potential bias in these findings. The current evidence for the clinical efficacy for treating diabetes is still weak. Nevertheless, these findings warrant further studies.

\section{Conclusion}

There is an increasing interest in E. alatus as a potential antidiabetic agent. More than 100 chemical constituents have been isolated and identified from E. alatus. The main chemical classes include flavonoids, terpenoids, steroids, phenylpropanoids, cardenolides, phenolic acids, and alkaloids. $E$. alatus has been demonstrated with hyperglycemic activity in vivo. The hypoglycemic activity E. alatus may be related to its effects on insulin signaling and glucose metabolism, including stimulating insulin secretion, improving affinity 
TABLE 8: Clinical studies of $E$. alatus for diabetic conditions.

\begin{tabular}{|c|c|c|c|c|}
\hline $\begin{array}{l}\text { Number of } \\
\text { patients }\end{array}$ & Preparation/compound & Treatment & Outcome measures/outcome & Reference \\
\hline 57 & $\begin{array}{l}\text { E. alatus formula containing } \\
\text { other herbs }\end{array}$ & $\begin{array}{l}\text { Oral, daily } \\
\text { per dose, for } \\
3 \text { months }\end{array}$ & $\begin{array}{c}\text { Fasting blood glucose and } 24 \mathrm{~h} \text { urine glucose } \\
\text { levels } \\
30 \text { cases with marked improvement } \\
19 \text { cases improved } \\
8 \text { cases no effect } \\
\text { Total effective rate: } 86 \% \\
\end{array}$ & {$[55]$} \\
\hline 58 & $\begin{array}{l}\text { E. alatus formula containing } \\
\text { other herbs }\end{array}$ & $\begin{array}{l}\text { Oral, daily } \\
\text { per dose, } \\
\text { average } \\
\text { medication } \\
\text { for } 37.2 \text { days. }\end{array}$ & $\begin{array}{c}\text { Fasting blood glucose level } \\
21 \text { cases remarkable effect } \\
28 \text { cases effective } \\
9 \text { cases no effect } \\
\text { Effective rate: } 84.4 \%\end{array}$ & {$[56]$} \\
\hline 100 & $\begin{array}{l}\text { E. alatus formula containing } \\
\text { other herbs }\end{array}$ & $\begin{array}{l}\text { Oral, daily } \\
\text { per dose, for } \\
4 \text { months }\end{array}$ & $\begin{array}{c}\text { Fasting blood glucose and urine glucose levels, } \\
\text { clinical symptoms } \\
40 \text { cases showed remarkable effect } 51 \text { cases } \\
\text { effective } \\
9 \text { cases failed } \\
\text { Total effective rate: } 91 \% \\
\end{array}$ & [57]. \\
\hline 1 & E. alatus decoction & $\begin{array}{l}\text { Oral, daily } \\
\text { per dose, for } \\
20 \text { days }\end{array}$ & $\begin{array}{l}\text { Hypoglycemic effects } \\
\text { Reduced blood and urine glucose and } \\
\text { increased body weight }\end{array}$ & {$[58]$} \\
\hline 80 & $\begin{array}{l}\text { E. alatus formula containing } \\
\text { other herbs }\end{array}$ & $\begin{array}{l}\text { Oral, daily } \\
\text { per dose, for } \\
30 \text { days }\end{array}$ & $\begin{array}{l}\text { Fasting blood glucose, } 2 \mathrm{~h} \text { postprandial blood } \\
\text { glucose values } \\
\text { Treatment group: } 32 \text { cases effective ( } 80 \%) \text { and } 8 \\
\text { cases no effect }(20 \%) \\
\text { Control group: } 22 \text { cases effective (55\%) and } 18 \\
\text { cases no effect ( } 45 \%)\end{array}$ & {$[47]$} \\
\hline
\end{tabular}

of insulin and receptor, increasing insulin sensitivity and tolerance, and reducing insulin resistance. It may also act as PPAR $\gamma$ agonist and aldose reductase inhibitor. Further study on the bioactive compounds of E. alatus and its pharmacology may help to develop new agents for treating diabetes and diabetic complications.
Abbreviations
AR: $\quad$ Aldose reductase
DPP-IV: Dipeptidyl peptidase IV
E. alatus: Euonymus alatus
GC-MS: Gas chromatography-mass spectrometry
LDL: Low-density lipoprotein
NO: $\quad$ Nitric oxide
PPAR $\gamma$ : Peroxisome proliferator activated receptor gamma
PTP1B: Protein tyrosine phosphatase $1 \mathrm{~B}$
SOD: $\quad$ Superoxide dismutase
STZ: $\quad$ Streptozotocin
TNF- $\alpha$ : Tumor necrosis factor-alpha.

\section{Competing Interests}

The authors declare that they have no competing interests.

\section{References}

[1] Jiangsu New Medical College, Dictionary of Chinese Materia Medica, Guijianyu, Shanghai Scientific and Technical Publishers, Shanghai, China, 1986.

[2] Research Group, "The preliminary study on the pharmacological effects Euonymus alatus," Journal of Traditional Chinese Medicine, vol. 4, pp. 28-30, 1977.

[3] S. Kitanaka, M. Takido, K. Mizoue, and S. Nakaike, "Cytotoxic cardenolides from woods of Euonymus alata," Chemical and Pharmaceutical Bulletin, vol. 44, no. 3, pp. 615-617, 1996.

[4] Z. F. Fang, Studies on the Chemical Constituents and Antitumor Activities of Euonymus alatus, Shenyang Pharmaceutical University, Shenyang, China, 2007.

[5] W. Wang, J. Wang, D. Zhao, H. Liu, W. Zhou, and K. Chen, "Comparison of Spatholobus suberectus Dum, Euonymus alatus (Thunb.) Sieb. and Eupolyphaga sinensis Walker on regulation of plasma lipid," China Journal of Chinese Materia Medica, vol. 16, no. 5, pp. 299-320, 1991.

[6] F. Qi, G. S. Liu, J. Yu et al., "Euonymus alatus effects on blood glucose and blood lipids of experimental diabetic mice," Chinese Journal of Information on Traditional Chinese Medicine, vol. 5, no. 7, pp. 19-20, 1998.

[7] D.-B. Huang, "An experimental research on inhibition of immediate and delayed type hypersensitivity by the $70 \%$ ethanolic extract from euonymus alatus," Chinese Pharmacological Bulletin, vol. 19, no. 6, pp. 686-688, 2003. 
[8] S. M. Lang, D. N. Zhu, B. Y. Yu, J. L. Zhao, Q. J. Wang, and Y. Q. Yang, "Hypoglycemic effects of extracts and constituents from Euonymus alatus," Journal of China Pharmaceutical University, vol. 34, no. 2, pp. 128-131, 2003.

[9] Z. L. Qi, M. W. Bai, P. Bai et al., "Observation of Fufang euonymus alatus mixture in the treatment of chronic nephritis," Henan Journal of Preventive Medicine, vol. 11, no. 1, p. 64, 2000.

[10] L. G. Ye and H. G. Zhou, "Examples of Euonymus alatus application," The Journal of New Chinese Medicine, vol. 35, no. 1, pp. 62-63, 2003.

[11] Z. E. Piao, "Clinical observation of Euonymus alatus in the treatment of cor pulmonale," Heilongjiang Medical Journal, vol. 2, no. 3, pp. 4-6, 1978.

[12] Y. P. Yang and Y. M. Xiu, "Synchronous observation of the effects of Juanxiao tang for thromboxane B2/6-keto-PGF1 $\alpha$ and superoxide dismutase in patients with asthma," Journal of Jiangxi University of Traditional Chinese Medicine, vol. 8, pp. 2930, 1996.

[13] X. B. Dong, "Clinical observation of treatment of allergic disease with Euonymus alatus," Journal of Traditional Chinese Medicine, vol. 4, p. 39, 1978.

[14] H. S. Yan, "The clinical application of Euonymus alatus," Primary Journal of Chinese Material Medicine, no. 1, p. 48, 1992.

[15] D. Chang, X. L. Li, and J. S. Nan, "Primary observation of clearing heat and freeing strangury effects of Euonymus alatus," China Journal of Chinese Materia Medica, vol. 25, no. 2, article 125,2000 .

[16] L. L. Dong, X. G. Bu, Y. T. Mu et al., "Determination of total flavonoids in different parts of Euonymus alatus," Information on Traditional Chinese Medicine, no. 6, p. 41, 1997.

[17] Y. Zhang, G. Xiao, L. Sun, Y. Wang, Y. Wang, and Y. Wang, "A new flavan-3-ol lactone and other constituents from Euonymus alatus with inhibitory activities on $\alpha$-glucosidase and differentiation of 3T3-L1 cells," Natural Product Research, vol. 27, no. 17, pp. 1513-1520, 2013.

[18] Y. Y. Ba, R. B. Shi, Q. Y. Liu et al., "Chemical compositions of Guijianyu (Ramulus Euonymi Alatae)," Journal of Beijing University of Chinese Medicine, vol. 35, no. 7, pp. 480-483, 2012.

[19] K. Chen, D. J. Pan, and G. Y. Xu, "Flavonoid constituents in Euonymus alatus," Chinese Traditional and Herbal Drugs, vol. 17, no. 3, pp. 1-3, 1986.

[20] Y. F. Shen, K. Q. Lin, D. Y. Zhu et al., "Study on active constituents of euonymus alatus," Journal of Hebei Medical University, no. 4, pp. 1-3, 1982.

[21] Y. Liu, X. Zhou, X. J. Gong et al., "Studies on chemical constituents of Euonymus alatus (Thunb.) Sieb. III," Chinese Traditional and Herbal Drugs, vol. 41, no. 11, pp. 1780-1781, 2010.

[22] S.-Y. Jeong, P.-H. Nguyen, B.-T. Zhao et al., "Chemical constituents of Euonymus alatus (Thunb.) Sieb. and their PTP1B and $\alpha$-glucosidase inhibitory activities," Phytotherapy Research, vol. 29, no. 10, pp. 1540-1548, 2015.

[23] L. Zhang, Y. Zou, X.-S. Ye, J. Zhang, W.-K. Zhang, and P. Li, "Chemical constituents from twigs of Euonymus alatus," China Journal of Chinese Materia Medica, vol. 40, no. 13, pp. 2612-2616, 2015.

[24] Y. Liu, X. Zhou, and X. J. Gong, "Studies on chemical constituents of Euonymus alatus (Thunb.) Sieb. I," West China Journal of Pharmaceutical Sciences, vol. 24, no. 2, pp. 107-109, 2009.
[25] X. Zhou, Y. Liu, and X. J. Gong, "Studies on chemical constituents of Euonymus alatus (Thunb.) Sieb. II," Chinese Pharmaceutical Journal, vol. 44, no. 18, pp. 1375-1377, 2009.

[26] H. R. Kang, H. J. Eom, S. R. Lee et al., "Bioassay-guided isolation of antiproliferative triterpenoids from Euonymus alatus twigs," Natural Product Communications, vol. 10, no. 11, pp. 1929-1932, 2015.

[27] Z.-H. Yan, Z.-Z. Han, X.-Q. Hu et al., "Two new sesquiterpenes from Euonymus alatus," Helvetica Chimica Acta, vol. 96, no. 1, pp. 85-92, 2013.

[28] H. Ishiwata, Y. Shizuri, and K. Yamada, "Three sesquiterpene alkaloids from Euonymus alatus forma Striatus," Phytochemistry, vol. 22, no. 12, pp. 2839-2841, 1983.

[29] E. J. Jeong, J. H. Cho, S. H. Sung, S. Y. Kim, and Y. C. Kim, "Inhibition of nitric oxide production in lipopolysaccharidestimulated RAW264.7 macrophage cells by lignans isolated from Euonymus alatus leaves and twigs," Bioorganic and Medicinal Chemistry Letters, vol. 21, no. 8, pp. 2283-2286, 2011.

[30] Y. Liu, X. Zhou, and Z. N. Yang, "Study on chemical components of essential oil from Evonymus alata by GC-MS," Cjtcmp Magazines, vol. 24, no. 10, pp. 1293-1295, 2009.

[31] W. J. Xia, H. B. Cheng, and L. Zhang, "Experimental study on treatment of type-2 diabetes with Euonymus alatus," Shaanxi Journal of Traditional Chinese Medicine, vol. 22, no. 8, pp. 505$507,2001$.

[32] J. E. Li, L. Wang, L. L. Qin et al., "Effects of winged euonymus twig on insulin resisitance and adipo-cytokines in T2DM rats," Guiding Journal of Traditional Chinese Medicine and Pharmacy, vol. 16, no. 11, pp. 1-3, 2010.

[33] S. H. Park, S. K. Ko, and S. H. Chung, "Euonymus alatus prevents the hyperglycemia and hyperlipidemia induced by high-fat diet in ICR mice," Journal of Ethnopharmacology, vol. 102, no. 3, pp. 326-335, 2005.

[34] M. M. Zhao, M. Z. Xie, L. D. Li et al., "Effect of Euonymus alatus on islet $\beta$-cell in type 2 diabetic rats," Journal of Hunan University of Traditional Chinese Medicine, vol. 30, no. 3, pp. 1416, 2010.

[35] B. Chang, C. Jin, W. Zhang et al., "Euonymus alatus in the treatment of diabetic nephropathy in rats," American Journal of Chinese Medicine, vol. 40, no. 6, pp. 1177-1187, 2012.

[36] Y. B. Li, H. T. Chang, P. Li et al., "The inhibitory effect of different extraction parts of 21 kinds of traditional Chinese medicine to human aldose reductase," Journal of Peking University (Health Sciences), vol. 36, no. 1, pp. 107-108, 2004.

[37] X.-K. Fang, Y. Gao, H.-Y. Yang et al., "Alleviating effects of active fraction of Euonymus alatus abundant in flavonoids on diabetic mice," American Journal of Chinese Medicine, vol. 36, no. 1, pp. 125-140, 2008.

[38] Y. J. Li, M. X. Gong, Y. Y. Lai et al., "Pharmacological effects of different extract fractions from Guijianyu (Euonymus alatus) on diabetic rats," Journal of Beijing University of Chinese Medicine, vol. 33, no. 3, pp. 179-182, 2010.

[39] Y. H. Chen, M. X. Gong, X. R. Lu et al., "Study on the constituents from Euonymus alatus in hypoglycemic effective extract," Chinese Journal of Experimental Traditional Medical Formulae, vol. 16, no. 7, pp. 42-43, 2010.

[40] L. Costantino, G. Rastelli, P. Vianello, G. Cignarella, and D. Barlocco, "Diabetes complications and their potential prevention: aldose reductase inhibition and other approaches," Medicinal Research Reviews, vol. 19, no. 1, pp. 3-23, 1999. 
[41] X.-K. Fang, J. Gao, and D.-N. Zhu, "Kaempferol and quercetin isolated from Euonymus alatus improve glucose uptake of 3T3L1 cells without adipogenesis activity," Life Sciences, vol. 82, no. 11-12, pp. 615-622, 2008.

[42] M. D. Ivorra, M. P. D’Ocon, M. Paya, and A. Villar, "Antihyperglycemic and insulin-releasing effects of $\beta$-sitosterol 3- $\beta$ $\mathrm{D}$-glucoside and its aglycone, $\beta$-sitosterol," Archives Internationales de Pharmacodynamie et de Therapie, vol. 296, pp. 224231, 1988.

[43] Y. Cai, C. Fan, J. Yan, N. Tian, and X. Ma, "Effects of rutin on the expression of PPAR $\gamma$ in skeletal muscles of $\mathrm{db} / \mathrm{db}$ mice," Planta Medica, vol. 78, no. 9, pp. 861-865, 2012.

[44] H. M. Li, J. K. Kim, J. M. Jang, C. B. Cui, and S. S. Lim, "Analysis of the inhibitory activity of Abeliophyllum distichum leaf constituents against aldose reductase by using high-speed counter current chromatography," Archives of Pharmacal Research, vol. 36, no. 9, pp. 1104-1112, 2013.

[45] S. D. Varma, I. Mikuni, and J. H. Kinoshita, "Flavonoids as inhibitors of lens aldose reductase," Science, vol. 188, no. 4194, pp. 1215-1216, 1975.

[46] I. Aydogdu, F. Zihnioglu, T. Karayildirim, D. Gülcemal, Ö. Alankuş-Çalişkan, and E. Bedir, " $\alpha$-Glucosidase inhibitory constituents of Linaria kurdica subsp. eriocalyx," Natural Product Communications, vol. 5, no. 6, pp. 841-844, 2010.

[47] Z. M. Zhao, "Clinical observation of compound Euonymus alatus preparation in the treatment of patients with impaired glucose tolerance," Hebei Medical Journal, vol. 34, no. 23, p. 3658, 2012.

[48] Z. F. Fang, Z. L. Li, Y. Wang et al., "Studies on chemical constituents from Euonymus alatus II," China Journal of Chinese Materia Medica, vol. 33, no. 12, pp. 1422-1424, 2008.

[49] E. J. Jeong, H. Yang, S. H. Kim, S. Y. Kang, S. H. Sung, and Y. C. Kim, "Inhibitory constituents of Euonymus alatus leaves and twigs on nitric oxide production in BV2 microglia cells," Food and Chemical Toxicology, vol. 49, no. 6, pp. 1394-1398, 2011.

[50] Y. Y. Ba, Q. Y. Liu, R. B. Shi, and L. Z. Zhang, "Studies on flavonoids from Euonymus alatus," Chinese Traditional and Herbal Drugs, vol. 43, no. 2, pp. 242-246, 2012.

[51] Z. Y. Jiang, W. H. Zhou, S. H. Lu et al., "Studies on the chemical constituents of the Chinese drug 'Gui Jian Yu' I," Journal of Nanjing College of Pharmacy, vol. 19, no. 2, pp. 93-95, 1982.

[52] Z. F. Fang, Z. L. Li, Y. Wang, W. Li, and H. M. Hua, "Chemical constituents from wing twigs of Euonymus alatus," Chinese Traditional and Herbal Drugs, vol. 38, no. 6, pp. 810-812, 2007.

[53] W.-H. Park, S.-H. Kim, and C.-H. Kim, "A new matrix metalloproteinase-9 inhibitor 3,4-dihydroxycinnamic acid (caffeic acid) from methanol extract of Euonymus alatus: isolation and structure determination," Toxicology, vol. 207, no. 3, pp. 383-390, 2005.

[54] U.-H. Jin, J.-Y. Lee, S.-K. Kang et al., "A phenolic compound, 5caffeoylquinic acid (chlorogenic acid), is a new type and strong matrix metalloproteinase-9 inhibitor: isolation and identification from methanol extract of Euonymus alatus," Life Sciences, vol. 77, no. 22, pp. 2760-2769, 2005.

[55] S. K. Sui and X. G. Li, "Clinical observation of 57 cases diabetes treated from blood stasis theory," Chinese Journal of Integrated Traditional and Western Medicine, vol. 12, no. 1, pp. 43-44, 1992.

[56] W. Y. Wu, "8805 Yuxiao powder add and subtract treatment of 58 cases of type 2 diabetes," Beijing Journal of Traditional Chinese Medicine, no. 3, p. 46, 1992.
[57] Y. J. Zhu, "Clinical observation of 100 cases of type 2 diabetes treated from the theory of liver," Shanghai Journal of Traditional Chinese Medicine, no. 7, pp. 19-20, 1999.

[58] J. Q. Hu and Y. Zhen, "The treatment of diabetes using Shenqi Maiwei Dihuang decoction with heavy added euonymus alatus," Chinese Journal of Ethnomedicine and Ethnopharmacy, vol. 9, no. 4, pp. 209-210, 2000. 


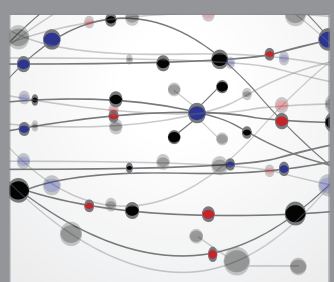

The Scientific World Journal
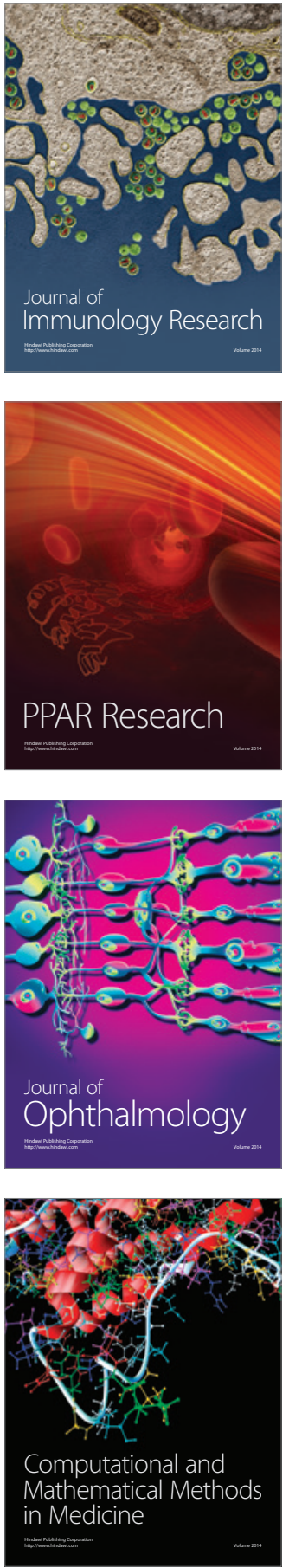

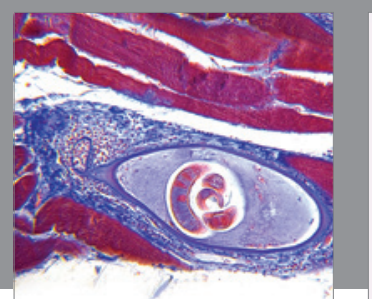

Gastroenterology Research and Practice

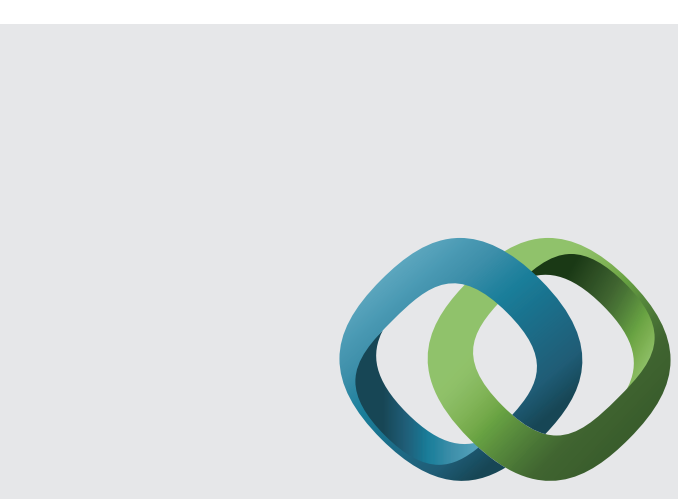

\section{Hindawi}

Submit your manuscripts at

http://www.hindawi.com
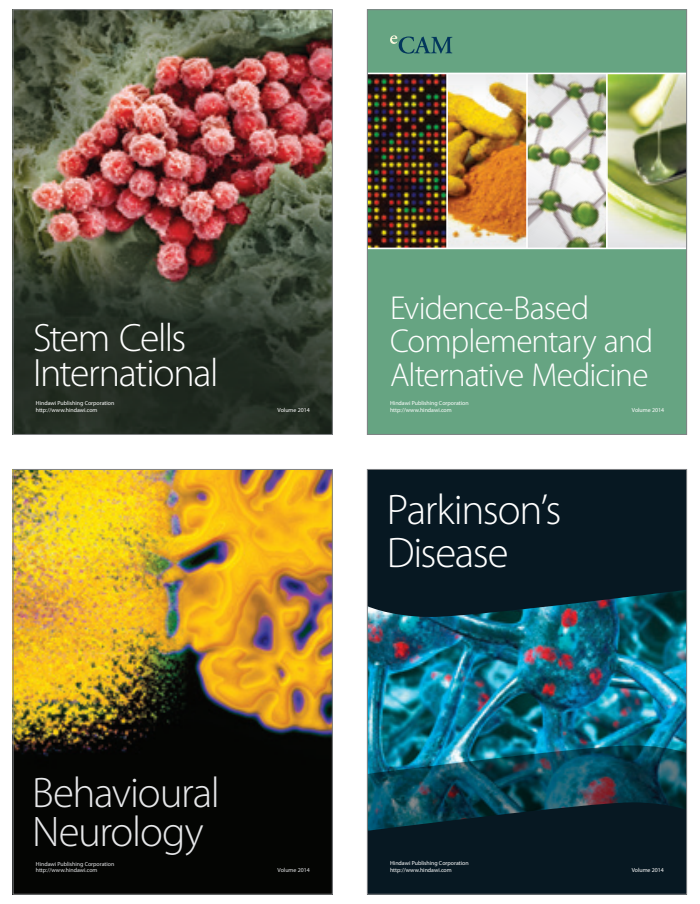
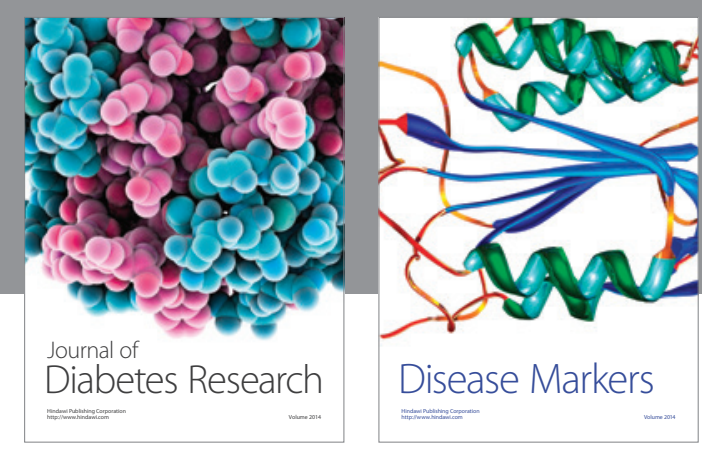

Disease Markers
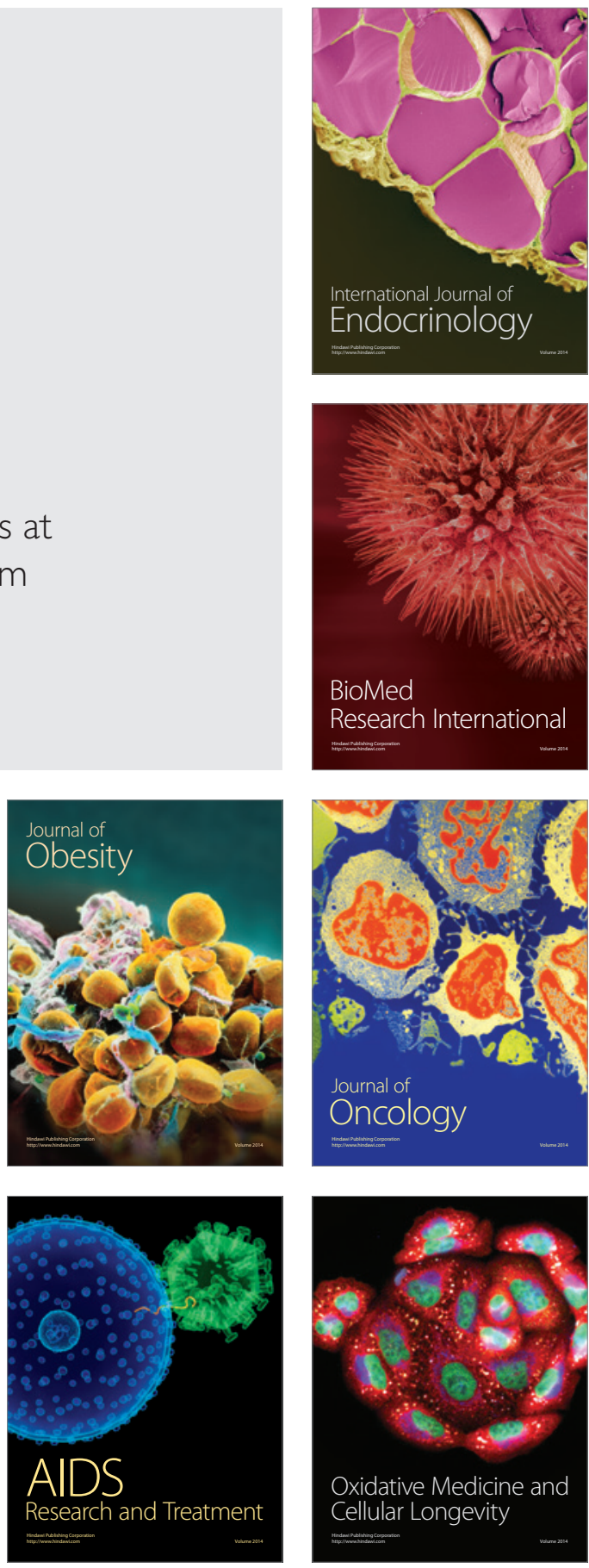